\title{
Bargaining Through Arguing: An Empirical Analysis Based on Speech Act Theory
}

\author{
KATHARINA HOLZINGER
}

\begin{abstract}
In a recent debate in political science, the terms "bargaining and arguing" have been construed as semantic opposites. The present article rejects this dichotomy and offers a new theoretical approach to clarify the logical and pragmatic relationship of bargaining and arguing as modes of the resolution of conflicts through communication. On the basis of speech act theory, a method for the empirical analysis of bargaining and arguing is developed and demonstrated with an example of conflict resolution by mediation. Four conclusions can be drawn. First, in empirical processes of communicative conflict resolution, in almost all cases both arguing and bargaining will be present. Second, only in the rare cases of pure conflicts over solely facts or values will arguing appear. Third, within the context of an interest conflict, arguing is not an alternative to bargaining, but a means for bargaining. Fourth, although bargaining and arguing have the potential to resolve certain types of conflicts, their success is difficult to predict and cannot be taken for granted.
\end{abstract}

Keywords arguing, bargaining, conflict resolution, discourse, mediation, negotiation, speech act theory

There has been a debate in international relations and public policy in recent years surrounding the dichotomy "arguing versus bargaining." In this debate, bargaining and arguing are depicted as opposing modes of communication. However, although bargaining and arguing are analytically distinct modes of communication, they are neither semantic opposites nor do they as communication processes form empirically disjunct classes. In particular, it has been shown that argumentation matters in bargaining situations (Majone, 1989). Therefore, the claim that arguing and bargaining occur, or are appropriate, in different contexts-the market and the forum-(Elster, 1986) is untenable as well.

The present article challenges the dichotomy both at the theoretical and the empirical level. It starts with a brief discussion of the theoretical debate, rejecting the dichotomy of arguing versus bargaining on theoretical grounds. A new approach to analytically clarify the terms arguing and bargaining is then made, based on the dimension that these two modes of communication have in common: Both are forms of conflict resolution through communication, although in resolving conflicts they fulfill different functions (Section 2).

Katharina Holzinger is Professor at the Institute for Political Science at the University of Hamburg.

Address correspondence to Katharina Holzinger, University of Hamburg, Institute of Political Science, Allendeplatz, 1, D-20146, Hamburg, Germany. E-mail: holzinger@mpp-rdg.mpg.de 
In empirical terms, bargaining and arguing can only be clearly distinguished at the level of individual utterances or speech acts. In the debate surrounding bargaining and arguing, so far no empirical studies have been conducted that analyze conflict resolution processes at the level of individual utterances. Only in this way can valid empirical claims be made about the relationship of bargaining and arguing in communicative conflict resolution. Consequently, the next stage is to develop a methodical instrument for analyzing empirical bargaining or arguing, based on the speech act theory of John Searle (1969) (Section 3). The method is demonstrated using a case of conflict over an environmental issue, the waste management plan in Neuss County, Germany (Section 4).

\section{Theory: Bargaining and Arguing}

\section{The Debate}

International relations theory and public policy have recently been entangled in a debate about two sets of opposite terms regarded as dichotomies: strategic action versus communicative action, on the one hand, and bargaining versus arguing, on the other. The debate has essentially been conducted in two contexts. Discussion of the term strategic action as opposed to communicative action began in 1994 in the German Zeitschrift für Internationale Beziehungen (ZIB; Journal for International Relations). It was concerned with the compatibility of rational choice theory, and game theoretic bargaining models in particular, with Habermas's $(1971,1984)$ discourse theory, as well as with the issue of which approach is better suited to the analysis of international relations. ${ }^{1}$ Within this discussion, communicative action has been equated with arguing and strategic action with bargaining (Risse et al., 1999). The debate was recently summarized by Risse (2000).

The second context is the debate in public policy, law, and sociology about the cooperative state, negotiation systems, and alternative conflict resolution processes. ${ }^{2}$ The debate has been influenced by economic negotiation theory, the praxeologic literature on negotiation which originated in the United States, and the European literature on the move away from the hierarchical state, as well as by approaches to participative and discursive resolutions to conflicts in society, such as mediation processes (Amy, 1987; Sussind \& Cruikshank, 1987). This debate is reflected, for example, in von Prittwitz (1996a).

In these debates, arguing and bargaining have been set up dichotomously as semantic opposites and alternative modes of communication; moreover, they have been correlated with certain contexts. The history of the pairing of "bargaining and arguing" can be traced back to Jon Elster (1986, p. 119; 1992, pp. 15-19). He distinguishes between arguing and bargaining as two ideal types of communication modes. The modes of communication are correlated to the metaphors "market" and "forum": Bargaining, according to Elster, is the predominant mode of the market, arguing that of the forum. Market and forum are in turn correlated with the theoretical concepts of rational choice and discourse theory (Elster, 1986). The conception of the citizen in social choice theory is, in his view, the same as the conception of the sovereign consumer. Whereas this may be appropriate for behavior in the market, it is not the case in politics, where the citizen decides things that not only affect her- or himself but others as well. Politics requires the forum, the public arena for discussion.

However, at this point the metaphors become too narrow in scope. Rational choice theory can analyze interest-oriented action beyond the economic sphere. Strategic action is not restricted to the market. Public political discussion is not free of interest positions. 
Furthermore, it is an open question whether, empirically, there is mainly bargaining in the market, and whether there is mainly arguing in politics. It was Elster himself who stated that in empirical communication both modes appear in concurrence (1992, p. 19), and consequently in both contexts, the market and the forum. Others have noted, as well, that arguing and bargaining usually appear together and that we observe an extensive amount of arguing in negotiations (cf. Majone, 1989; Benz, 1994; Saretzki, 1996; Risse, 2000). As a consequence, both the idea that arguing and bargaining are alternative modes of resolving one and the same conflict and the expectation that they appear in different social contexts cannot be fully correct.

Other approaches that deal with conflict resolution and negotiations have, in any case, never embraced the debate's stylized separation of the modes of communication into arguing and bargaining. In particular, there have been intensive and interdisciplinary investigations into negotiations through the Harvard Program on Negotiation since the 1950s. Their concept of negotiations has followed economic models (e.g., Nash, 1950; Raiffa, 1982), although there has also been much social-psychological research. Prescriptive, practice-oriented concepts have been developed here for bargaining that is both objective and consensus oriented. The most prominent of these is the Harvard concept, which formulates four precepts for rational and impartial negotiation (Fisher, Ury, \& Patton, 1997). Other political scientists who work on negotiation theory also accept that bargaining can be argumentative at the same time (Benz, 1994, pp. 112168). It remains to be explained why and when both modes appear, and their specific contribution to communicative conflict resolution.

\section{The Logical and Pragmatic Relationship of Arguing and Bargaining}

This section aims to analytically clarify the relationship between arguing and bargaining. The starting point of my argument is the meaning of the words, from which the two concepts derive their common dimension: Both are forms of conflict resolution through communication. I first present the meaning of both terms and then ask which function they perform in communication. Next, a typology of conflicts is introduced that serves to explain why, in most empirical political conflicts, both arguing and bargaining appear. Finally, the question is raised as to how and when both modes of communication can be effective in conflict resolution. From this, a number of conjectures about the relationship of arguing and bargaining in conflict resolution are derived.

The term arguing essentially means "justifying," or "giving reasons." ${ }^{3}$ Different kinds of positions can be justified, and the means of justification are manifold. Justifications can be good or bad, and they may or may not fulfill their purpose of "persuasion." The meaning of the term to negotiate is very broad. It generally describes overcoming obstacles and reaching agreement in particular. The term bargaining has a narrower meaning: "to negotiate and agree beforehand concerning trade, barter"; "to agree to buy or sell"; or "to agree to or obtain certain terms." It is not without reason that economic models of negotiation, which were after all developed for the exchange and trade of private goods, are called bargaining models.

As it is usually employed in political science, negotiating means reaching an agreement in a situation of potential conflict on the exchange of goods or other subjective values, or on controversial issues such as in a court hearing or parliamentary negotiations. This general meaning of negotiating is hard to distinguish from arguing, the objective of which is, after all, to achieve agreement through talking. Both rely on consensus, that is, agreement not achieved by a majority vote but by the assent of all participants. 
Both allow for compromise, that is, agreement based on concession on both sides. In bargaining, agreement is generally achieved by mutual adjustments to each other's demands; however, it is also possible in arguing for there to be "truth in the middle" and, hence, for there to be partial mutual persuasion.

If we leave aside the general meaning of negotiation as agreement through talking and restrict ourselves to bargaining in the narrower sense, then the bargaining ideal type describes the mutual adjustment of demands and wishes by virtue of giving way, either by forsaking one's own ideal goal or by acknowledging the other party's demands. The arguing ideal type, on the other hand, attempts to bring the other party to forsake its views or positions by persuasion. Arguing appeals to reason, bargaining to the willingness to make concessions. Arguing tries to resolve cognitive dissent, bargaining tries to bridge volitional differences.

Although arguing and bargaining are analytically distinct forms of verbal conflict resolution, this does not mean that they are alternatives or semantic opposites. They are not substitutes for each other; rather, they complement each other. Bargaining refers to modal logic (will or desire), whereas arguing refers to epistemological logic (belief and knowledge). One can argue for any kinds of "positions" or propositions, including truthfunctional (empirical), deontic (normative), and volitional propositions.

It is important to note that arguments can also be made for volitional propositions. It is for this reason that empirical negotiations generally involve a good deal of arguing (Majone, 1989; Benz, 1994, pp. 120-127). After all, in most cases of social relations a demand, or a rejection of one, must be justified. There is thus little sense in separating the argument from bargaining when analyzing a real world negotiation. The volitional objective and the argument supporting it belong together. The arguments then serve as instruments for the promotion of the volitional proposition.

Empirically, pure bargaining can scarcely ever be found in the way it is described in the economic model. There may be borderline cases where the pure, opposing will is accepted as legitimate and where only a "rational" distribution is sought. Such cases are most likely to be realized in market transactions. ${ }^{4}$ As a rule, however, justifications are to be found here too, referring to facts, values, and norms (cf. Benz, Scharpf, \& Zintl, 1992, p. 109).

There may be situations where the pure will is legitimate, for example, when someone says "I would like to have an ice-cream." However, justification becomes obligatory the moment volitions start to restrict or curb another party's will: "I want the ice-cream cheaper." "Why?" They must then be measured against others' claims and rights, against freedoms, norms, or distributional rules.

Basing the wish on a prior subjective wish is usually not sufficient. Facts, norms, and values have to be used as justification for the simple wish to be turned into a legitimately recognized wish. The proposition "I don't want a waste disposal site in my neighborhood" can, for example, be supported by the propositions "I don't want to be exposed to any health risk," "Everyone has the right not to have his/her health damaged by the public at large," and "Waste disposal sites are a danger to health." The wish is acknowledged as legitimate if there is agreement on the validity of the norm and of the proof of the empirical claim.

In arguing, empirical claims are shown to be true, norms to be valid, and so forth. Arguing is subject to certain normative requirements: Conclusions must be drawn logically and properly, and in order to prove empirical claims, specific methodological standards must be adhered to. Not every type of "position" can be justified with every type of statement. For example, factual claims are not appropriate to support a normative 
statement. In practice, there are often whole chains of argumentation made up of various types of propositions used for justification. In particular, when truth-functional propositions have to be proved - and it is not a question of trivial observable facts, but, for example, it is about the issue of whether waste disposal sites are a danger to health-the chain of arguments can be very long.

Arguing is always the means to an end, where the end is to persuade those addressed of the accuracy of a factual statement, the validity of a norm, or the fairness of a claim. It presupposes the existence of a speaker and an addressee or audience who shall be convinced. Moreover, the addressees need not necessarily want to persuade the speaker. Arguing can be unidirectional or reciprocal.

In bargaining, however, the speaker wants to induce the addressee(s) to give in, to make a concession, or to agree to a compromise, and the addressee wants to achieve the same with the speaker. Bargaining presupposes at least two parties to a conflict and partial reciprocity of their wills. An agreement is achieved solely among the parties; an audience does not play a role.

Although bargaining and arguing are thus different modes of communication, they are not alternative modes by which the same thing can be done and achieved. Both arguing and bargaining take place when disagreements or conflicts over facts, values, or interests are to be solved. It is the type of conflict that determines whether there will be bargaining, arguing, or a mixture of both. In the following, three types of conflict are distinguished as ideal types, according to what the conflict is about. The typology extends the approach of Aubert (1963).

1. Conflicts over facts are based on divergent beliefs about the world. The disagreements relate to entities that can be perceived or established intersubjectively. Such disagreements can be resolved by recourse to empirical information and logic. Conflicts that are purely over facts can (and should, according to general normative belief) be dealt with through pure arguing. The model for this is science. Whatever the correct position is in each case, it does not depend on the agreement of the parties to the conflict. One would not negotiate over the "truth," and there would not be a vote to determine which is the correct belief.

2. Conflicts over values and norms are based on disagreement regarding the validity of normative propositions. Such conflicts can be resolved by recourse to empirical information, logic, and prevailing values or norms. Conflicts over the validity of a norm or value can, by means of logic, be argued back to (higher ranking) values for which a general consensus exists. If contradictions are found, the conflict can be resolved by pure means of logic. However, whenever a disagreement over basic values remains, the conflict cannot be resolved by arguing. Values acquire validity as a result of the consensus of a society or culture; they depend on common assent and are subject to change. Conflicts over basic values indicate that these values may be changing. Positive norms acquire validity through voting and representation, at least in democratic societies.

3. Conflicts of interest are based on rival wishes and claims. Underlying the conflict is the scarcity of particular goods and the different subjective assessments made of the possible distributions or of the solution alternatives. Such conflicts are likewise partially resolved by recourse to facts, logic, and values or norms. As well as this, however, the subjective claims must be reconciled. Conflicts of interest are decided by those affected giving their assent, and here that means by subjective willingness. In a bargaining process, all of the participants must agree. 
The pure conflict of interest (free of all factual and normative disagreements) could be resolved by pure bargaining; however, a conflict of interest will rarely be free of normative and factual disagreement, and thus arguing is also needed.

In all three types, the attempt to resolve the conflict almost always involves arguing. Only in conflicts of interest, however, will bargaining occur. If one wants to know whether arguing or bargaining can be expected as a mode of resolving a conflict, the fundamental question to be asked is the following: Is it "only" a question of the proof of factual claims? Is it "only" about values? Or is it also about interests?

The analytical relationship of the types of conflict and the two modes of communicative conflict resolution is thus as follows:

- Whenever one is confronted with a pure conflict over facts, only arguing should occur.

- Whenever one is confronted with a pure conflict over values, only arguing should occur.

- Whenever there is conflict of interest involved, both arguing and bargaining are likely to occur. Only in the rare cases of claims that do not need legitimization might pure bargaining occur.

These are analytical sentences, not empirical hypotheses. They presuppose that the ideal types of conflicts occur in their pure forms, and that the parties act according to the normative ideas regarding how the respective type of conflict should be resolved (e.g., "truth cannot be bargained about"). These conditions are rarely given in empirical conflicts.

There are three reasons why, in empirical conflicts, both arguing and bargaining will occur in almost all cases. First, most real world conflicts will be a mixture of all three of the ideal types of conflicts. Conflicts of interest will be accompanied by conflicts over values and norms, and they will imply conflicts over facts. This is particularly true for political conflicts. The "share" of the respective ideal types of conflict will vary from case to case.

Second, resolution of conflicts over facts, values, or interests need not happen in the normatively desirable or appropriate forms in reality. For example, all types of conflicts can be "resolved" by using force. Both arguing and bargaining can be strategic or opportunistic. In an ideal type conflict over facts, strategic or opportunistic communication would be superfluous, as there is no interest by definition. In real world conflicts, however, factual claims of actors often serve their interest. Similarly, value conflicts are not free of interests, and thus we can expect strategic arguing or bargaining to be present.

Third, conflicts over facts, values, or interests are not always independent. As a consequence, the resolution of one part or aspect of the conflict can solve another aspect at the same time. Particular interests presuppose particular states of the world in order to be relevant at all. There can be disagreement on the state of the world. Depending on the answer to the factual question, a particular interest will or will not develop. For example, there may be disagreement over the question as to whether the emissions from a waste incineration plant pose significant health problems to the neighborhood. If the answer to this question were definitively "no," the people living in the neighborhood would not develop an interest in opposing the building of an incinerator.

For these reasons, it is difficult to empirically test the analytical correlations stated above, because in empirical conflicts almost inevitably both arguing and bargaining will occur. It will not be possible to classify the conflict resolution process as a whole as 
either an arguing or a bargaining process. Therefore, empirical analysis needs to distinguish between the complex communication situation, such as an international negotiation, a public debate, or an instance of wage bargaining, and the individual utterances made within such a communication situation. Only the latter can clearly be classified as belonging to the mode of arguing or bargaining. In bargaining, one would typically expect demands, offers, promises, concessions, or threats. In arguing, one would typically expect claims, justifications, conclusions, or contradictions. These can be established by linguistic means. On the basis of the individual utterances of participants, it can be analyzed when and to which end acts of arguing or bargaining appear in conflict resolution.

\section{The Effects of Arguing and Bargaining}

What can actually be achieved in conflict resolution by using arguments or by using acts of bargaining? How and under which conditions can they lead to agreement or consensus? I start with arguing.

First, arguing may change factual beliefs. This will be the case if the addressee of the argument believes that all implications of the argument are valid, that is, the addressee believes both in the logic of the argument and in the empirical evidence provided. If this is the case, the addressee will change his or her position. Second, arguing may change normative beliefs. This will be the case if the addressee comes to believe that the value inherent to the norm defended by the argument is something that should be achieved. Third, arguing may even change preferences, although this is less likely than with beliefs about facts or norms. It is less likely because arguing is directed at the cognitive sphere. Facts and values are also cognitive categories and can therefore be reached by arguments. Preferences are subjective volitions that are difficult to change by cognitive processes alone. It is therefore useful to make further distinctions.

First, arguing may change behavior without changing preferences. Behavior changes as a result of a change in factual or normative beliefs. One may believe that a certain preference is not "good" for oneself or for others and therefore exercise self-constraint. However, the preference as such is not extinguished. Second, arguing may change revealed preferences, but not true preferences. Revealed preferences change as a result of a belief in the existence of a social norm. The existence of the norm changes the revealed preferences of a person, but the actual preferences remain. We would call this person a hypocrite. Third, arguing may change true preferences, at least indirectly. Whenever arguments change behavior, this may lead to a change of preferences in the long run, as preferences are often a function of habit or of the cultural or social environment.

In sum, arguing has the potential to change factual and normative beliefs, as well as preference-related behavior and revealed and true preferences. The problem is that there is no automatism that turns an argument into a change of belief or preferences. Whether an argument is effective depends on the quality of the argument and on the attitude of the addressee. An argument will not be effective under the following conditions.

- The addressee does not believe in the argument, because he or she does not accept the values implied, does not trust the evidence provided, or finds the logic dubious. There are two possible reasons for this: Either the argument or parts of it are in fact not valid, or the addressee does not have the cognitive capacity to understand the argument. 
- The addressee does not want to believe in the argument. This will happen if a change in factual or normative beliefs would require a change in preferences or behavior, but the addressee does not want to change preferences, interest positions, or behavior. Put more generally, the interest may override the norm or the evidence. The volition is stronger than the cognition. In these cases, the addressee will usually pretend not to believe in the argument in order to avoid internal dissonances or external problems with the legitimacy of his or her claims or behavior.

As a consequence, it is almost impossible to predict when arguing will be successful, because it is difficult to generally outline the empirical conditions under which the volitions override the cognitions for an actor, the addressees have the capability to understand the arguments, and the arguments made are valid ones. It is somewhat easier to determine ex post whether, in an arguing process, participants have changed their factual or normative beliefs or even preferences. This faces the difficulty, however, that we can observe behavior but not intra-psychic events such as changes in beliefs or preferences. We cannot fully trust in what participants say to each other or to the researcher. The may state that there was a change (or no change) in beliefs or preferences for strategic reasons. Thus, we cannot know about true beliefs or preferences; however, we can observe at least agreements or disagreements in the process and whether this implies change in cognitive or volitional positions of the participants.

How does bargaining lead to conflict resolution, and when is it effective? Bargaining works through the mutual adjustment of claims or demands of the bargainers by way of giving in. In bargaining, the participants are not required to change their factual or normative beliefs or to change their preferences. They are "only" required to give way, to accommodate others, to forsake their own ideal goal in order to reach consensus. The agreement is usually a compromise compared to the original demands of the participants.

Bargaining has the potential to induce the parties to make such concessions. Economic bargaining theory predicts that bargaining will be effective if all sides gain from a negotiated agreement compared to their best alternative to a negotiated agreement (e.g., Nash, 1950; Raiffa, 1982; Fisher et al., 1997). Rational actors will accept any agreement that is better than the situation without agreement. In pure conflict situations, where the gains of one actor are the losses of the others (such as "zero-sum games"), agreement is more difficult to find.

Rational bargaining theory has its limitations, however. We know from bargaining experiments that actors are not always willing to accept any solution that improves their position compared to the situation without negotiation. Normative considerations, such as fairness, often lead to the breakdown of a bargaining process, although there is much room for rational compromise (Güth, Schmittberger, \& Schwarze, 1982; Roth, 1995). On the other side, fairness considerations might lead the parties in a pure conflict situation to give in to find a "good" or "fair" solution.

Thus, the effectiveness of bargaining depends on willingness to compromise on the part of the bargaining parties. Their willingness is determined by two factors. Bargaining will not be effective if (a) the parties perceive their best alternative to the negotiated agreement to be better than their expected negotiated agreement, or (b) the parties judge the expected negotiated agreement to be not a "good" solution in terms of their normative beliefs, and in particular, if they judge the expected agreement to be unfair. As in the case of arguing, it is thus difficult to predict when bargaining will be 
successful, first because this hinges on the participants' subjective expectations of the negotiated agreement and their best alternative, and second because it is a priori unclear under which conditions rationality will override normative beliefs, or vice versa. Similarly, it is easier to ex post determine concessions made in a bargaining process, comparing the agreement reached to the initial bargaining positions. As preferences cannot be observed, however, we will never know how big the concessions "really" were on which side, because the revealed initial preferences (positions) might have been strategic ones.

\section{Conjectures and Research Questions}

The above discussion of the logical, pragmatic, and empirical relationship of arguing and bargaining can be summarized in the form of four claims:

1. In the resolution of empirical political conflicts by means of communication, the joint appearance of both communication modes, arguing, and bargaining, can be expected as a rule.

2. The sole appearance of arguing can be expected only if an empirical conflict is a pure conflict over facts or values, or only if such a part of an empirical conflict will be treated separately in the process of conflict resolution.

3. In conflicts of interest, arguing serves as an instrument for bargaining. Bargaining positions have to be justified by arguments; arguing is (sincerely or strategically) used to support bargaining positions. Thus, in conflicts of interest, arguments can be expected to relate to the bargaining goals of the parties.

4. Arguing has the potential to change factual and normative beliefs as well as preferences. However, arguing is not automatically successful. The same is true for bargaining: It has the potential to reconcile diverging interests but is not automatically successful.

For the analysis of real-world processes of conflict resolution by means of communication, these conjectures can be turned into empirical research questions. Addressing these questions presupposes that arguing and bargaining can clearly be distinguished as acts of communication.

1. Given that the conflict under consideration is either a conflict of interest or a mixture of conflict types, do both arguing and bargaining occur? How much bargaining and how much arguing do we find, and how does this relate to the different ideal types of conflict present in the empirical case?

2. Given that the empirical conflict represents the rare case of a pure conflict over facts or values, can in fact only arguing be observed? If this is not the case, are there "hidden" interests? Did the participants try to "resolve" the conflict in an inappropriate mode?

3. Given a conflict of interest, can the instrumental pragmatic relationship of arguing and bargaining be established? Do the arguments refer to the preferences, interest positions, and bargaining goals of the parties?

4. Have participants in the process been persuaded or convinced by arguing? Did they (or some of them) change their factual beliefs? Did they change normative beliefs? In the case of conflicts of interest, did they change preferences or interest positions? Has bargaining led to concessions in the case of some parties? 


\section{Method: Speech Act Analysis}

Conflict resolution processes are complex communication situations. They presuppose several utterances of several interlocutors. They consist of combinations of many individual speech acts. Whereas it is hardly possible empirically to classify complete communication situations as belonging to the bargaining or arguing mode, there is no problem classifying individual utterances.

In this section, an instrument is developed for the analysis of empirical communicative conflict resolution on the basis of classifying speech acts, and it will be applied to a case of environmental conflict resolution in Neuss, Germany. The section starts with an introduction to the basics of speech act theory. Second, the conflict in Neuss, the procedure, and the results of the mediation will be portrayed. It is surely unusual to present the empirical case in the method section. However, both speech act theory and the case information are necessary in order to understand all elements of the method and its empirical operationalization. Third, the instrument for the analysis of the empirical case will be specified in detail.

\section{Speech Act Theory}

As the instrument of speech act analysis has not been applied before in this form in social science, the method is described before the results are presented. The instrument is based on speech act theory, an area of linguistic pragmatics developed by Austin (1962) and Searle (1969). Pragmatics is concerned with reconstructing the meaning of language in a given context. Unlike semantics, it is not concerned with what is "said" but with what is "meant." Pragmatics presupposes both semantics and knowledge of existing norms and conventions relevant to the speech situation in question. Speech act theory starts with the assumption that actions are performed by speaking: Speech is "intentional behavior governed by rules" (Searle, 1974). A speech act, according to Austin (1962) or Searle (1969), is the action that a speaker performs by making an utterance. It consists of the following:

- the locutionary act, that is, the pure utterance of sounds and words

- the acts of reference and predication, which make up the propositional content of the utterance

- the illocutionary act, that is, the action the speaker performs by making the utterance

- where applicable, a perlocutionary act, that is, the effect on the addressee brought about through the speech act ${ }^{5}$

Illocutionary acts, which are what we are concerned with in the following, are described by so-called performative verbs: to claim, to justify, to demand, to offer, etc. These verbs may occur in the utterances through which the respective illocutionary act is performed. This need not necessarily be the case, however. The illocution to demand can be expressed by saying "Give me half of. . . ." or "I hereby demand half of. . . ." Basically, however, all illocutionary acts can be rendered, without changing meaning, in the form "I hereby claim (etc.) that. . . . ." Other illocutionary indicators besides the performative verbs are the position of the verb, intonation, modal particles, interrogative particles and other lexical means.

Searle developed an instrument for the explication of illocutionary acts. He made 
explicit the conditions explicit that must be valid in order for it to be possible for each individual illocutionary act to actually be performed by the utterance of a sentence. Searle differentiates several groups of constitutive rules:

1. Rules of the propositional content: What can be said?

2. Introductory rules: What social preconditions must apply?

3. Rules of sincerity: What must one assume the speaker's motivation to be?

4. Essential rules: What does the action consist of?

In the example to claim that, these rules are as follows (Searle, 1983, p. 100):

1. Any proposition $p$.

2. (a) The speaker has proof (reasons etc.) of the truth of $p$.

(b) It is not obvious to either the speaker or the hearer that the hearer knows $p$ and does not need to be reminded of it.

3. The speaker believes $p$.

4. Serves to ensure the content, that $p$ stands for a real material situation.

In the following, speech act theory is transformed into a method for analyzing empirical communication processes for the purpose of identifying bargaining and arguing speech acts in conflict resolution processes. It should by now have become clear that speech act analysis is first and foremost a qualitative method. The individual utterances must be classified as speech acts and their semantic relationships taken into consideration as well. Using speech act theory, the course and the results of arguing or bargaining processes can, in principle, be understood qualitatively.

The method can also be applied quantitatively by counting certain types of speech acts. Since the research question posed in this article is not concerned with reconstructing the course and result of the mediation of the specific case, but rather with the relationship of arguing and bargaining in conflict resolution, a quantitative analysis is carried out in the following example. This requires standardization and, at the same time, sacrificing differentiation and nuances. In particular, quantitative analysis loses the fact that individual arguing or bargaining speech acts can be of completely different relevance for the course of the process as a whole.

\section{The Case: Conflict and Course of the Proceedings}

For the operationalization of the method, some information about the case is needed. What was the conflict about? Who were the actors, and which goals did they pursue? What kind of procedure was used, what happened, and what was the final outcome? What kind of conflict is represented by the Neuss case, and why was it chosen for analysis?

As the authorities responsible for the disposal of domestic waste, in Germany counties are required to produce waste management plans on a regular basis. The draft for the 1991 waste management plan of the county of Neuss triggered a controversy that became the subject of the mediation. The new plan provided for a household waste incinerator. An expert report commissioned by the county authorities had already led to a provisional choice of three potential locations for siting the incinerator. These plans met with fierce opposition from the population and the county's environmental groups.

The Neuss County Council expressed interest in resolving the conflict by means of 
mediation. Mediation procedures are negotiation processes involving a third neutral party, the mediator (Amy, 1987; Susskind \& Cruikshank, 1987; Hoffmann-Riem \& SchmidtABmann, 1990). Between March 28, 1992, and August 27, 1993, nine mediation sessions were held. In total, 27 organizations took part: eight local governments, all four political parties of the County Council, five county citizens' action groups, the business associations and environmental associations that operated at the county level, and, finally, two churches.

In principle, the plan for waste management and the incineration of nonrecyclable waste had the support of the county administration, most of the local governments, the Social Democratic Party (SPD), the Christian Democratic Party (CDU), and the Free Democratic Party (FDP), as well as that of the three business associations (hereafter called the "supporters"). The Green Party, the environmental associations, the citizens' action groups, and two of the church parish communities from the proposed incinerator sites rejected the waste management plan and the incinerator plant itself (hereafter the "opponents"). Of the three provisionally selected sites, Grevenbroich-Neurath was regarded by all of the participants as the most likely one. The crux of the conflict was determined by two factors: acceptance or rejection of waste incineration, on the one hand, and rejection of or support for Grevenbroich-Neurath as the site location, on the other.

At the ninth mediation session, the county administration announced its intention to submit a resolution to the County Council for securing the site of a thermal waste treatment plant. The environmental associations, citizens' action groups, and the Greens declared that they could not agree to this, and stood by their call for biological-mechanical treatment of nonrecyclable waste. All of the other participants in the mediation supported the position of the county administration or abstained from voting. The mediation was concluded without reaching consensus on nonrecyclable waste treatment technology and the site location. In the course of the proceedings, however, consensus had been achieved on far-reaching measures for waste avoidance and recycling (cf. Holzinger \& Lackmann, 1995, pp. 48-54).

The conflict over the Neuss waste management plan was chosen for analysis because it was primarily a conflict of interest between various public and private actors (Holzinger, 2001a). However, there was also much disagreement over scientific facts and some disagreement over norms. The effects of different strategies of waste avoidance and of different technologies for waste treatment, the impacts of the planned facilities at the three potential sites, and the interpretation of legal provisions were in dispute. Finally, there were also value-laden beliefs about the issue of waste incineration, although values were not at the center of the problem. The conflict hence represents a mixture of all three types of conflict distinguished above, which makes it typical of most political conflicts both at the national and the international level.

The fact that the procedure for conflict resolution was mediation needs some qualification. The mediation group had no authority to adopt a binding agreement. The formal decision was to be made by the County Council. However, all crucial actors were represented in the mediation, and in particular all political parties. The majority party in the County Council, the SPD, had initiated the mediation together with the county administration. Both the SPD and the CDU promised that they would respect any consensus found in the mediation when making the final decision in the County Council. Thus, a consensual agreement could be expected to be politically implemented at the county level. 


\section{The Instrument for the Analysis of the Neuss Case}

In order to explain the part bargaining and arguing played in the Neuss mediation, a speech act analysis was carried out of the transcript of the recordings made at the mediation sessions. The analysis had three aims.

First, as the conflict over the Neuss waste management concept was primarily a conflict of interest combined with a factual conflict, we could reckon to find both bargaining and arguing sequences. Therefore, the purpose of the speech act analysis was to establish the respective amount of bargaining and arguing that took place, as well as the distribution of both modes over the course of the procedure. To this end, a record was made of when there was explicit bargaining or arguing, by whom and about what.

Second, it has been shown that in the context of an interest conflict, arguments serve as justifications for bargaining positions. Arguments, however, can also serve as a means of discussing and clarifying factual matters, as far as those appear within a conflict. Whenever the factual matters are closely related to the subjective interests and bargaining goals of a party to the conflict, this kind of arguing can be judged as "interest oriented." Whenever arguments pursue the end of clarifying factual matters or the end of mediating between the parties, they can be judged as "consensus oriented." The second aim of the speech act analysis was therefore to find out whenever "bargaining through arguing" took place, in other words, whenever a bargaining position was backed up by justification based on facts or values. For this purpose, it was necessary to establish in the speech act records what the goals and positions of the parties in conflict were, and where arguing and bargaining speech acts demonstrated a clear reference to these.

Third, the mediation in Neuss ended without a consensus. We can therefore expect that, overall, neither arguing nor bargaining was successful. The analysis of the speech acts can show, however, whether there was at least some acceptance of others' demands, some accommodation and concession, or partial consensus at the bargaining level and whether there was at least some approval of others' arguments and some agreement on the arguing level. On the basis of speech acts, however, it cannot be shown whether there was "real" persuasion. To address this question, some results from a concluding written survey and from interviews with mediation participants are provided.

For the purpose of analyzing the mediation transcripts, a number of speech acts were defined that can be expected to occur in bargaining, as well as a number of speech acts that are central to arguing. There are a large number of performative verbs for both bargaining and arguing. We restricted ourselves here to the essential functions of bargaining and arguing, treating performative verbs with the same or similar meanings as synonyms (see Appendix A). In each instance, the meaning of these performative verbs is taken to be the meaning which they have within bargaining or arguing. Some verbs, for example to reject, to agree to, to concede, or to take back, may occur in the context of either bargaining or arguing in natural languages. One can reject an offer, and one can reject an argument, or one can agree to a judgment and agree to a demand. These verbs can be classified as either bargaining or arguing only with regard to the propositional content of the utterance. This does not pose any practical problem, however.

The speech acts listed in Appendix A were defined following the rules of Searle (1969). For each speech act, we formulated the four rules as in the example to claim that given above. These definitions served as a codebook for classification of the individual speech acts in the Neuss mediation.

Next, the transcripts were scrutinized to find explicit bargaining speech acts. ${ }^{6}$ For each utterance in the data, a record was made of the respective speaker and addressee, 
the illocutionary intention, illocutionary indicators (only to be certain of the classification), and the propositional content of the utterances themselves. Since direct observation of the proceedings had given rise to the suspicion that bargaining was particularly prevalent where the procedure itself was concerned, the propositional content was classified as being at the procedural or the substantial level. In addition, a third category, the relationship level, had to be distinguished: Many of the utterances that formally had to be classified as arguing or bargaining speech acts referred to attitudes and emotions toward the mediation itself or other participants. ${ }^{7}$ Finally, the record includes the explicitly revealed or implied goals of bargaining speech acts.

In the same way speech acts were then recorded that could be classified as arguing. Here, too, the revealed or implied goal of the argument was recorded alongside the utterance in the database. Thus, it is was possible to classify arguments as "interest oriented" versus "consensus oriented." Arguing speech acts were also classified according to their content as belonging to the substantial, procedural, and relationship levels. In addition, there were some arguments that were not conflict related. ${ }^{8}$

Questioning, wishing, and establishing consensus were among the most common speech acts in the mediation. Consensus-related speech acts were hence recorded in a separate database with regard to their pragmatic function. No distinction was drawn, however, as to whether they should be classified as bargaining or arguing. Appendix B gives four examples for speech act records: a bargaining speech act, a consensus speech act, an interest-oriented arguing act, and a consensus-oriented arguing speech act.

The various groups' bargaining goals were reconstructed from the record of the first mediation session, from documents that had emerged in the run up to the mediation within the public debate, and from qualitative interviews with the participants in the mediation (Holzinger \& Weidner, 1997). Although the mediation was concerned with Neuss County's waste management plan as a whole, the key issue of contention was the planned construction of a nonrecyclable waste incinerator in Grevenbroich-Neurath. The substantial bargaining and arguing goals need to be seen in this context. The two main substantial goals are to support the cause for or against the construction of an incinerator for nonrecyclable waste and the cause for or against the potential site, GrevenbroichNeurath. Appendix B provides an example for each of them. Supporting the cause against or in favor of the construction of a biological-mechanical plant for the treatment of nonrecyclable waste is equivalent to the negative of the first goal.

At the same time, the goal of waste reduction played a significant part. For waste incineration in the county to be justified, there had to be an annual minimum quantity of nonrecyclable waste. Opponents hence strove to have the amount of nonrecyclable waste be kept as low as possible, by calling for stronger measures for waste avoidance and by attempting to undercalculate the statistics of the prognosis. Supporters, on the other hand, tried to overcalculate the nonrecyclable waste prognosis.

Another goal was the opponents' demand for additional expert reports on the potential for waste avoidance and recycling, the treatment technology, a comparison of site locations, and legal reports. The opponents hoped that these reports would furnish them with arguments against waste incineration or against the locations provisionally selected for the incinerator site.

As well as substantial goals, political-strategic goals appear in the mediation: The desire to win time on the part of the opponents of waste incineration is reflected in several calls for a moratorium on political decisions on the waste management plan. The authorities, on the other hand, clearly desired to demonstrate openness, flexibility, and cooperation. The political parties were aiming for a settlement of the conflict before 
the local government elections, which were due soon (cf. Holzinger \& Weidner, 1997; Holzinger, 2001a).

Finally, goals were classified as communicative goals if the arguments were presented either in order to clarify factual questions or misunderstandings or in order to mediate between the parties. An example of the latter, where the mediator proposes a compromise, is given in Appendix B.

One final observation on the method needs to be made with regard to classifying individual arguments under goals. The goals, motivations or views of individual speakers can never be established with certainty. Even when an arguing or bargaining goal is explicitly stated in an utterance, this need not be the "true" goal. In classifying arguments under goals, we have therefore not attempted to record the respective speaker's "true subjective goals." We classified an argument as belonging to a particular goal of the above list when it was objectively (factually, logically) suited to support it. For example, in speech act 2,35,1357 in Appendix B, the argument that the health report had found a high level of sinusitis in Grevenbroich-Neurath clearly supports the case against Grevenbroich-Neurath as a site for the incinerator; in speech act 4,146,5858 the proposal of the mediator to have both a biological treatment plant and an incinerator for the residual waste was clearly aimed at reconciling positions.

\section{Evidence: Speech Act Analysis of the Neuss Case}

The total volume of the transcripts of the nine mediation sessions amounted to approximately 785 pages. Nearly all of the types of speech acts we had selected in fact occurred. ${ }^{9}$ The total number of speech acts recorded was 1,748 (Table 1). Of these, 651 fall under bargaining speech acts, 985 under arguing, and 112 under consensus speech acts. From these, however, 483 bargaining, arguing, and consensus speech acts have to be deducted,

Table 1

Number of speech acts

\begin{tabular}{llr}
\hline Speech acts & \multicolumn{1}{c}{ Level } & No. \\
\hline Bargaining & Procedure & 235 \\
& Relationship & 19 \\
& Substantial (conflict related) & 397 \\
Arguing & Procedure & 100 \\
& Relationship & 73 \\
& Substantial (not conflict related) & 44 \\
& Substantial (conflict related) & 768 \\
Consensus & Procedure & 11 \\
& Relationship & 100 \\
& Substantial (conflict related) & 483 \\
All speech acts & Procedure, relationship (not conflict related) & 1,265 \\
& Substantial (conflict related) & 1,748 \\
\hline
\end{tabular}


as they are concerned with the procedure $(235,100$, and 11$)$, with the relationship between the participants (19,73, and 1), or they are not related to the conflict (44). Bargaining (397), arguing (768), and consensus-related speech acts (100) at the substantial level therefore amounted to 1,265 speech acts. In the following, only these 1,265 speech acts that directly relate to the substance of the conflict will be taken into account. In some instances, results from the semantic analysis are presented. In these cases, the source is given using the number of the meeting, page, and line in the transcript.

\section{Joint Appearance of Arguing and Bargaining}

A look at the respective percentages of the bargaining speech acts in Table 2 leaves the unavoidable impression that the mediation must have been fairly confrontational: $D e$ mands are the most frequent (29\%), and rejections make up the third largest group with $17 \%$. Suggestions (18\%) are neutral in character. Of the "more friendly" speech acts, promises are the largest group, with no less than $11 \%$, followed by acceptance of demands and suggestions (8\%). Like concessions, these are reactive bargaining speech acts. On the other hand, offering, suggesting compromises, and accommodating occur very rarely. What is striking is that the number of threats was so small. Even in a process where the parties were obviously not inclined to "friendly overtures" toward each other, explicit threatening, which is often regarded in political science as constitutive for bargaining (Saretzki, 1996; Elster, 1992, p. 15), only occurred eight times. ${ }^{10}$

The arguing speech acts (Table 3) again reveal the confrontational character of the proceedings: The most frequent is to contradict $(21 \%)$, whereas to approve and to concede together only amount to $10 \%$. In total, the neutral and informative speech acts do, however, predominate; to ask, claim, establish, suspect, and inform together account for $44 \%$. However, it must not be forgotten that it is not only claims but also questions and other arguing speech acts that may represent an attempt to support one's position. This

Table 2

Bargaining speech acts on the substantial level

\begin{tabular}{lrrrrrr}
\hline Speech act & Supporters & Opponents & Mediator & Experts & Total & $\%$ \\
\hline demand & 20 & 69 & 20 & 7 & 116 & 29 \\
offer & 13 & 3 & 2 & 1 & 19 & 5 \\
suggest & & & & & & \\
$\quad$ of which: suggest & & & & & & \\
$\quad$ a compromise & 101 & 272 & 283 & 80 & 736 & 18 \\
accommodate & 16 & 2 & 0 & 0 & 18 & 5 \\
promise & 39 & 0 & 3 & 0 & 42 & 11 \\
threaten & 0 & 5 & 3 & 0 & 8 & 2 \\
accept & 22 & 3 & 0 & 8 & 33 & 8 \\
decline & 38 & 18 & 10 & 3 & 69 & 17 \\
concede & 8 & 1 & 0 & 0 & 9 & 2 \\
uphold & 0 & 3 & 1 & 0 & 4 & 1 \\
ascertain nonagreement & 1 & 1 & 4 & 0 & 6 & 2 \\
$\quad$ Total & 167 & 131 & 80 & 19 & 397 & 100 \\
$\quad \%$ & 42 & 33 & 20 & 5 & 100 & \\
\hline
\end{tabular}


Table 3

Arguing speech acts on the substantial level

\begin{tabular}{lcccrrr}
\hline Speech act & Supporters & Opponents & Mediator & Experts & Total & $\%$ \\
\hline claim & 38 & 29 & 13 & 50 & 130 & 17 \\
establish & 12 & 2 & 9 & 37 & 60 & 8 \\
suspect & 4 & 2 & 1 & 1 & 8 & 1 \\
ask & 29 & 52 & 32 & 0 & 113 & 15 \\
inform & 16 & 1 & 1 & 6 & 24 & 3 \\
conclude & 11 & 14 & 8 & 6 & 39 & 5 \\
justify & 47 & 18 & 10 & 32 & 107 & 14 \\
approve & 15 & 4 & 8 & 33 & 60 & 8 \\
contradict & 60 & 36 & 20 & 42 & 158 & 21 \\
concede & 4 & 3 & 2 & 9 & 18 & 2 \\
insist & 7 & 3 & 3 & 5 & 18 & 2 \\
judge & 3 & 8 & 0 & 20 & 31 & 4 \\
ascertain nonagreement & 1 & 0 & 1 & 0 & 2 & $<<1$ \\
$\quad$ Total & 247 & 172 & 108 & 241 & 768 & 100 \\
$\%$ & 32 & 23 & 14 & 31 & 100 & \\
\hline
\end{tabular}

also holds true for argumentative speech acts in the narrowest sense: to justify and to conclude $(19 \%)$. Besides the experts, it was the supporters who were foremost in producing justifications. In the case of the county administration, this often meant justification of their planning and their position. It was the experts who, together with the county administration, occasionally conceded a point.

Although the large number of contradictions suggests much disagreement, in fact this was only confirmed explicitly in two cases. There is a different picture for consensus. This is not surprising, as disagreement will be perceived in any event. Ascertaining consensus, however, is an important procedural step: If a consensus has been ascertained without objection, it is difficult to unilaterally cancel it later. The greatest percentage of speech acts relating to consensus came from the mediator (71 of 100 speech acts). This is again not surprising, since it is after all the mediator's job to bring about consensus between the opposing parties.

In sum, both bargaining and arguing speech acts were found, as expected in a conflict combining divergent interests and disagreements over facts and values. Seen quantitatively, there was more arguing than bargaining in the Neuss mediation. This can be seen in the number of speech acts (768 and 397), as well as in speech act density (speech acts per page: 1.0 and 0.5 ). Looked at in more detail, this distribution is certainly due to the unique features of the proceedings. Considerable time was dedicated to clarification of factual questions, and the negotiations were then broken off very abruptly. An analysis of the speech distribution over the course of the proceedings shows how the appearance of arguing and bargaining is related to the resolution of the various aspects of the conflict.

\section{Speech Act Distribution and Conflict Types}

Although the Neuss mediation was primarily a conflict of interest, there was a lot of conflict over factual issues and some conflict over norms involved. Moreover, there 
were several "subconflicts," for example, over the waste reduction goals of the county, the waste treatment technology, and the location of the treatment plant. Is there any relationship between the distribution of speech acts over individual mediation sessions and the types and subjects of conflict addressed in these meetings?

Table 4 gives details of the distribution of bargaining and arguing speech acts across all of the mediation sessions and of the density of bargaining and arguing in the individual sessions. The duration of the sessions varied from about two to six hours; hence, a comparison using absolute figures is difficult. In the neighboring column, numbers of speech acts are thus related to the typescript page.

Bargaining is concentrated in the second to fifth sessions. It peaks in the fourth session, although there is another high occurrence in the final session. Between these sessions, bargaining speech acts are close to zero. A fairly similar pattern emerges for consensus speech acts. Arguing begins in the third and fourth sessions; tails off in the fifth; remains high throughout the sixth, seventh, and eight sessions; and finally decreases substantially again in the final session.

The density measure shows the development more clearly: Arguing is particularly prevalent in Sessions 6, 7, and 8. If we compare the development of bargaining with arguing, it can be seen that there are sessions that really consisted of arguing only (sixth to eighth) and sessions in which there was both bargaining and arguing (third, fourth, fifth, and ninth). There are no sessions in which arguing speech acts do not occur. However, there was little arguing in the second session.

These developments resulted from the particular topics under discussion during the sessions. The mediation dealt with several different matters for negotiation: the allocation of the expert reports, the waste reduction goals, the treatment technology, and the issue of the site location. There were hence several "negotiation units."

- In the first session, the participants' positions were formulated as to what was to be expected of mediation; a rough line was developed for the proceedings; and

Table 4

Distribution of conflict-related speech acts across the mediation sessions

\begin{tabular}{|c|c|c|c|c|c|c|c|c|c|}
\hline \multirow[b]{2}{*}{ Session } & \multirow{2}{*}{$\begin{array}{c}\text { No. } \\
\text { of } \\
\text { pages }^{a}\end{array}$} & \multicolumn{2}{|c|}{ Bargaining } & \multicolumn{2}{|c|}{ Consensus } & \multicolumn{2}{|c|}{ Arguing } & \multicolumn{2}{|c|}{ Total } \\
\hline & & Number & Density $^{b}$ & Number & Density $^{b}$ & Number & Density $^{b}$ & Number & Density $^{b}$ \\
\hline 1 & $70^{\mathrm{b}}$ & 23 & 0.3 & 6 & 0.1 & 21 & 0.3 & 50 & 0.7 \\
\hline 2 & 82 & 50 & 0.6 & 1 & 0.0 & 11 & 0.1 & 62 & 0.8 \\
\hline 3 & 105 & 66 & 0.5 & 10 & 0.1 & 95 & 0.9 & 171 & 1.6 \\
\hline 4 & 222 & 144 & 0.5 & 54 & 0.2 & 268 & 1.2 & 466 & 2.1 \\
\hline 5 & 52 & 52 & 1.0 & 12 & 0,2 & 40 & 0.8 & 104 & 2.0 \\
\hline 6 & 87 & 3 & 0.0 & 3 & 0.0 & 127 & 1.5 & 133 & 1.5 \\
\hline 7 & 46 & 1 & 0.0 & 1 & 0.0 & 85 & 1.8 & 87 & 1.9 \\
\hline 8 & 54 & 9 & 0.2 & 1 & 0.0 & 81 & 1.5 & 91 & 1.7 \\
\hline 9 & 68 & 49 & 0.7 & 12 & 0.2 & 40 & 0.6 & 101 & 1.5 \\
\hline Total & 786 & 397 & 0.5 & 100 & 0.1 & 768 & 1.0 & 1,265 & 1.6 \\
\hline
\end{tabular}

${ }^{a}$ Minus all presentations given by the experts.

${ }^{b}$ Speech acts per page of transcript.

${ }^{c}$ An estimate, as the only written record available was in shorthand. 
requests for information were put to the county administration. Bargaining and arguing speech acts occur in equal quantity.

- The second session was given over to planning and negotiating the additional expert reports. Altogether, there are 51 bargaining and consensus-seeking speech acts and only 11 arguments.

- In the third and fourth sessions, the expert report opposing the waste management plan was presented. In these sessions, more far-reaching measures for waste avoidance and recycling were negotiated. In the third session there were 76 bargaining (including consensus) and 95 arguing speech acts, and in the fourthvery long-session the numbers were 198 and 268.

- The fifth session was used to plan the expert report on treatment technologies. This session has the greatest density of all speech acts, including the procedural and relationship levels, which is in keeping with the session's actual controversial nature. Bargaining and consensus (64 times) and arguing (40 times) are equally balanced.

- An expert hearing took place in the sixth session, to which each side invited one expert on the legal questions and one on technology. The expert report comparing technologies was discussed in the seventh session, and the report comparing the potential sites was discussed in the eighth meeting. It was decided that the procedure for these three sessions would be confined to questioning the experts, and that the "discussion among ourselves" was to be postponed to a session solely dedicated to this purpose. It is therefore not surprising that there were almost no bargaining speech acts in these sessions. Arguing speech acts occur 127 times in the sixth session, 85 times in the seventh, and 81 times in the eighth session. The corresponding figures for bargaining plus consensus are 6, 2, and 10 .

- The final session began with the county administration's ultimatum, which was endorsed by the SPD and the CDU. Two offers of compromise made by the opponents were rejected. We find 61 bargaining and consensus speech acts and 40 arguments.

Whenever the parties to the conflict actually tried to accommodate their interest positions, such as in the selection of experts, the selection of tasks for and questions to the experts, and in negotiating the future waste reduction goals for the county, both bargaining and arguing can be found. Quantitatively, arguing was prevalent in the fourth and fifth meetings, although there was certainly a negotiation going on and consensus was found. There were a number of literally "bargained" agreements (Holzinger \& Lackmann, 1995), which is a consequence of the fact that waste reduction goals can be expressed in numbers (so and so many tons of waste reduced).

Meetings 6 to 8 were devoted solely to clarifying scientific and legal questions. The conflict of interest was postponed, and thus only factual conflict was to be discussed. This situation comes close to an ideal-type conflict over facts. We would expect to find only arguments here, and, in fact, only a very small number of bargaining utterances were made in these sessions. The interest conflict came back, however, in the last meeting with a predominance of bargaining.

The distribution of the speech acts over the meetings has shown that arguing speech acts clearly predominated in the discussions of precisely those subjects that brought about the breakdown of negotiations (choice of treatment technology and location). The analysis of the goal references below shows that arguing did not take place separately from the bargaining goals. Arguing was related to the interests of the parties. 


\section{Bargaining Through Arguing}

The principal goals that bargaining and arguing refer to have already been stated above. Table 5 differentiates between references to the treatment technology, the potential site of the waste incinerator, the reduction in waste amounts, the expert reports, politicalstrategic goals, and communicative goals (clarifying and mediating). Other substantial goals are goals that were mentioned in a bargaining or arguing sequence but could not be classified under the main goals. " The totals for bargaining and arguing speech acts have been drawn up separately, as a substantial difference can be shown.

Most of the speech acts were directed at the treatment technology (37\%), followed by the reduction in waste amounts $(27 \%)$ and the expert reports $(14 \%)$. The fact that the question of the site location was mentioned so little (10\%) is connected to the fact that the issue was initially omitted and only became important in the penultimate session. Political-strategic goals (4\%) are voiced by the supporters in particular. This reflects the structure of the conflict: The political parties and the county administration were trying to solicit support for acceptance of their plan. With regard to the opponents' politicalstrategic goals, there are four instances where the Greens called for a moratorium on the final decision. The communicative goals (7\%) are mainly pursued by the mediator, but not exclusively. In a few cases, other participants also perform speech acts that serve purely to clarify a concrete fact or to mediate. In the case of the mediator, clarifying predominates (53 instances); speech acts aimed at mediation are substantially fewer (36).

The fact that the reduction in waste amounts occurs in such a relatively large number of speech acts (in 332 speech acts compared with 443 on the main point of controversy, the treatment technology) is due to the way the proceedings were conducted: Whereas waste amounts were discussed in detail, leading to a fairly large number of consensual conclusions, discussion of the technology and the site location, although

Table 5

Goal references in bargaining and arguing

\begin{tabular}{|c|c|c|c|c|c|c|c|c|c|c|}
\hline \multirow[b]{2}{*}{ Goals } & \multirow{2}{*}{$\begin{array}{l}\text { Sup- } \\
\text { porters }\end{array}$} & \multirow{2}{*}{$\begin{array}{l}\text { Oppo- } \\
\text { nents }\end{array}$} & \multirow[b]{2}{*}{ Mediator } & \multirow[b]{2}{*}{ Experts } & \multicolumn{2}{|c|}{$\begin{array}{c}\text { Total for } \\
\text { bargaining }\end{array}$} & \multicolumn{2}{|c|}{$\begin{array}{l}\text { Total for } \\
\text { arguing }\end{array}$} & \multicolumn{2}{|c|}{$\begin{array}{c}\text { Overall } \\
\text { total }\end{array}$} \\
\hline & & & & & No. & $\%$ & No. & $\%$ & No. & $\%$ \\
\hline $\begin{array}{l}\text { Treatment/ } \\
\text { technology }\end{array}$ & 129 & 132 & 13 & 169 & 73 & 17 & 370 & 47 & 443 & 37 \\
\hline Site location & 32 & 42 & 6 & 39 & 20 & 5 & 99 & 13 & 119 & 10 \\
\hline $\begin{array}{l}\text { Reduction of } \\
\text { waste amounts }\end{array}$ & 160 & 67 & 59 & 46 & 144 & 34 & 188 & 24 & 332 & 27 \\
\hline Expert reports & 70 & 68 & 28 & 3 & 119 & 28 & 50 & 6 & 169 & 14 \\
\hline $\begin{array}{l}\text { Other substantial } \\
\text { goals }\end{array}$ & 4 & 6 & 0 & 1 & 8 & 2 & 3 & $<1$ & 11 & 1 \\
\hline $\begin{array}{l}\text { Political-strategic } \\
\text { goals }\end{array}$ & 41 & 5 & 2 & 0 & 35 & 8 & 13 & 2 & 48 & 4 \\
\hline $\begin{array}{l}\text { Communicative } \\
\text { goals }\end{array}$ & 1 & 0 & 82 & 6 & 23 & 6 & 66 & 8 & 89 & 7 \\
\hline Total & 437 & 320 & 190 & 264 & 422 & 100 & 789 & 100 & 1,211 & 100 \\
\hline$\%$ & 36 & 26 & 16 & 14 & 35 & & 65 & & 100 & \\
\hline
\end{tabular}


begun at the arguing level, was never really conducted at the bargaining level because the mediation ended abruptly and in disagreement as a result of the county administration's proposal.

The two columns in Table 5 that show the totals for bargaining and arguing speech acts highlight this difference clearly: While there was much arguing about treatment technology (370 references), there was little bargaining (73). The results on the issue of site location are quite similar (99 and 20). Whereas $60 \%$ of all arguing speech acts were aimed at the key contentious issues of incineration and site location, only $22 \%$ of all bargaining speech acts targeted these questions. On the other hand, there are 188 arguing speech acts concerning the reduction in waste amounts compared with 144 bargaining speech acts. The goal of influencing the expert reports was mentioned in as many as 119 bargaining speech acts but only in 50 arguing utterances. There are two reasons for this. First, the waste reduction issue and the writing of the expert reports were the two issues actually resolved in the mediation procedure. Second, it was obviously also possible to negotiate openly on these questions, in other words, to simply make demands or to reject them. As far as the contentious issues of incineration and site location were concerned, the parties initially attempted to support their position principally by reference to facts, values, and norms. What would have happened if the county administration and the political parties had taken a more flexible line and had carried on negotiating remains open to speculation.

Examination of the goal references shows that not only was bargaining strategic, but that arguing was as well: It took place as a means of promoting self interests. This confirms the analysis of the role of bargaining and arguing in interest conflicts presented above, and thus Schimmelfennig's idea of "rhetoric action" (1997). Only the mediator acted to clarify and mediate. Arguing was not primarily consensus oriented.

\section{No Changes in Beliefs or Preferences}

As the mediation ended in disagreement over the main issue of contention, bargaining and arguing obviously did not prove successful in resolving this conflict. From this final result, we cannot infer, however, that there were not partial concessions or that some actors were not convinced by particular arguments. How much persuasion and how much successful bargaining can we find?

Persuasion rarely took place. There was much arguing, but only a small number of participants changed their factual beliefs. The first indicator for this is that only $10 \%$ of the arguing speech acts consisted of to approve and to concede (Table 3). Moreover, no one stated explicitly that he or she had been persuaded or convinced. However, this could be due to strategic action: The actors pretended not to have been persuaded as a consequence of their interests.

In a written survey held after the conclusion of the mediation, responses to the statement "As a result of the mediation procedure I have changed my views on some important factual issues" were distributed across a 5-point scale from "agree" to "disagree," as follows: $9 \%, 20 \%, 13 \%, 29 \%$, and $29 \%$ (Holzinger, 2001b). Thus, about $60 \%$ do not seem to have changed their beliefs, but about $30 \%$ did so. These answers are probably less strategic, as they were given after the mediation and thus could not influence its result, and they were given to a neutral party, the researches.

As mentioned above, there were a number of bargained agreements on the issues of waste reduction goals and expert report selection in Sessions 3 to 5. Table 4 shows that most of the consensus speech acts occurred in these meetings (76 out of 100). Thus, 
there was some successful bargaining in these parts of the procedure. As described above, this was more a matter of exchange and compromise than of good arguments.

Over the whole mediation, however, there was not much change in preferences or interest positions. To concede, to accept, and to accommodate amount to only $15 \%$ of the bargaining speech acts (Table 2). This was confirmed in the participants' concluding evaluations in the final session: It was felt by both the opponents and the supporters that a lot had been "learned" in factual matters, but essentially none of the participants had changed their position $(9,35,1298 ; 9,37,1395 ; 9,65,2437)$. The latter points to the existence of strong interests.

In a first round of qualitative interviews conducted at the beginning of the mediation, many of the parties to the conflict did in fact not believe that a consensus was possible (Fietkau \& Weidner, 1998, pp. 245-250). Obviously, the participants were mainly oriented toward their own self-interest. There was not much willingness to make concessions or to become persuaded by others' arguments. During the procedure, the participants simply did not give up their interest positions. Nevertheless, a great amount of arguing took place. Arguing proved to be perfectly compatible with strategic action and bargaining.

\section{Conclusion}

The data from the Neuss mediation show that the theoretical interpretation suggested in this article for the terms bargaining and arguing is found to be valid in empirical evidence, and that hence more progress can be made in empirical analysis with this interpretation than with the dichotomy of two allegedly alternative modes of communication established in the literature. The empirical analysis yielded the following results.

First, the analysis of a communicative conflict resolution procedure illustrated that bargaining and arguing can scarcely be separated empirically. One does not occur without the other when a political conflict combines several ideal types of conflict and when it includes a conflict of interest. Both conditions were fulfilled in the Neuss case, and the two modes of communication did in fact occur in parallel. Quantitatively, arguing was even represented to a greater extent than bargaining.

Second, only in an ideal type of conflict over facts or values can the appearance of pure arguing be expected. Sessions 6 to 8 of the Neuss mediation came close to an ideal-type conflict over facts, because it was explicitly agreed upon to discuss only factual matters and to postpone discussion of interests-related questions. In fact, almost only arguing appeared.

Third, it was possible to demonstrate that bargaining and arguing are not alternatives or opposites. The two modes of communication fulfill different functions in the pursuit of the same goals; they are not alternative mechanisms for achieving a solution. In the context of a conflict of interests, arguing is a means of bargaining so long as it refers to the interests of the parties. The vast majority of arguing speech acts in the Neuss procedure promoted a goal that was in the interests of one of the parties. The negotiation goal was targeted either directly using bargaining speech acts or indirectly using arguing speech acts.

Fourth, in the Neuss case neither arguing nor bargaining was very successful. Changes in beliefs and preferences rarely took place, and this situation was obviously not sufficient to turn the mediation into a successful enterprise. There were some consensual agreements and compromises on minor issues, but there was no consensus on the central issues of the conflict. It can therefore be assumed that for one or both parties to the 
conflict, either interests were stronger than factual and normative beliefs or the expected negotiated agreement was perceived to yield no gain compared to the expected situation without a negotiated agreement. This result is case specific, however.

\section{Notes}

1. In particular, the following contributions to the ZIB debate discussed this issue: Müller (1994, 1995), Schneider (1995), Keck (1995, 1997), and von Prittwitz (1996a).

2. Cf. Ritter (1979), Scharpf (1991, 1993, 1997), Benz (1994), and Voigt (1995).

3. The meanings are taken from the New Standard Dictionary of the English Language.

4. Moreover, there are social situations where no explicit justification of demands is needed or given (cf. Searle, 1969; Habermas, 1984). This is the case if there is a legitimate hierarchy such that one actor's demands are accepted by the other actors as a result of the social relationship. However, this is typically not the case in negotiations.

5. An example of a perlocutionary act is to persuade: It brings about a change of opinion in the hearer.

6. The full textual analysis based on the speech act definitions was carried out independently by three researchers. All three had studied linguistics and were hence familiar with speech act theory.

7. For example a member of the Greens says to the senior county director: "You're talking like a hypocrite now, as if there was openness [in the question of the location]" (claim) and then, following two requests by the mediator, "I take it back" (withdrawal).

8. There was a long discussion, for example, about the question of why 10 years before one of the waste disposal sites in the county had been planned as a pit disposal instead of as a surface disposal. This had no meaning at all for the actual conflict.

9. An exception is to take back. Neither offers nor demands, nor arguments, were ever taken back. The only instance of taking back occurred at the relationship level (see Note 8).

10. Taken separately, the threats become even less significant. For example, the mediator's three threats were threats to pull out of the proceedings, made several times in the same situation. In the same situation, the BUND threatened to exit as well.

11. An example was the discussion of whether rotting or fermenting was the better biological form of treatment.

\section{References}

Amy, D. J. (1987). The politics of environmental mediation. New York: Columbia University Press.

Aubert, V. (1963). Competition and dissensus: Two types of conflict and of conflict resolution. Journal of Conflict Resolution, 7, 26-42.

Austin, J. L. (1962). How to do things with words. London: The William James Lectures.

Benz, A. (1994). Kooperative Verwaltung: Funktionen, Voraussetzungen, Folgen. Baden-Baden: Nomos.

Benz, A., Scharpf, F. W., \& Zintl, R. (1992). Horizontale Politikverflechtung. Zur Theorie von Verhandlungssystemen. Frankfurt: Campus.

Elster, J. (1986). The market and the forum: Three varieties of political theory. In J. Elster \& A. Hylland (Eds.), Foundations of social theory (pp. 103-132). Cambridge, England: Cambridge University Press.

Elster, J. (1992). Arguing and bargaining in the Federal Convention and the Assemblée Constituante. In R. Malnes \& A. Underdal (Eds.), Rationality and institutions: Essays in honour of Knut Midgaard (pp. 13-51). Oslo: Universitetsforlaget.

Fietkau, H.-J., \& Weidner, H. (1998). Umweltverhandeln: Konzepte, Praxis und Analysen alternativer Konfliktregelungsverfahren. Berlin: Edition Sigma. 
Fisher, R., Ury, W., \& Patton, B. (1997). Getting to yes: Negotiating an agreement without giving in. London: Arrow Business Books.

Güth, W., Schmittberger, R., \& Schwarze, B. (1982). An experimental analysis of ultimatum bargaining. Journal of Economic Behavior and Organization, 3, 367-388.

Habermas, J. (1984). Theory of communicative action (Vol. 1). London: Heinemann.

Habermas, J. (1971). Vorbereitende Bemerkungen zu einer Theorie der kommunikativen Kompetenz. In J. Habermas \& N. Luhmann (Eds.), Theorie der Gesellschaft oder Sozialtechnologie (pp. 101-141). Frankfurt: Suhrkamp.

Hoffmann-Riem, W., \& Schmidt-Aßmann, E. (1990). Konfliktbewältigung durch Verhandlungen (Vols. I \& II). Baden-Baden: Nomos.

Holzinger, K. (2001a). Negotiation in public policy-making: Exogenous barriers to succesful dispute resolution. Journal of Public Policy, 21, 81-106.

Holzinger, K. (2001b). Evaluating environmental mediation: Mediation in the Waste Management Programme of Neuss County, Germany. Results of a participant survey. Mediation Quarterly, 18, 397-427.

Holzinger, K., \& Lackmann, B. (1995). Das Neusser Mediationsverfahren: Ausgangssituation, Konfliktbeteiligte, Verfahrensverlauf und Sachergebnisse (WZB Discussion Paper FS II 95307). Berlin: Wissenschaftszentrum Berlin für Sozialforschung.

Holzinger, K., \& Weidner, H. (1997). Das Neusser Mediationsverfahren im politischen Umfeld (WZB Discussion Paper FS II 97-303). Berlin: Wissenschaftszentrum Berlin für Sozialforschung.

Keck, O. (1995). Rationales kommunikatives Handeln in den internationalen Beziehungen. Zeitschrift für Internationale Beziehungen, 2, 5-48.

Keck, O. (1997). Zur sozialen Konstruktion des Rational-Choice-Ansatzes. Einige Klarstellungen zur Rationalismus-Konstruktivismus-Debatte. Zeitschrift für Internationale Beziehungen, 3, 139-151.

Majone, G. (1989). Evidence, argument and persuasion in the policy-process. New Haven, CT: Yale University Press.

Müller, H. (1994). Internationale Beziehungen als kommunikatives Handeln. Zeitschrift für Internationale Beziehungen, 1, 1-44.

Müller, H. (1995). Spielen hilft nicht immer: Die Grenzen des Rational-Choice-Ansatzes und der Platz der Theorie kommunikativen Handelns in der Analyse internationaler Beziehungen. Zeitschrift für Internationale Beziehungen, 2, 371-391.

Nash, J. (1950). The bargaining problem. Econometrica, 18, 155-162.

von Prittwitz, V. (Ed.). (1996a). Verhandeln und Argumentieren. Dialog, Interessen und Macht in der Umweltpolitik. Opladen: Leske \& Budrich.

von Prittwitz, V. (1996b). Verständigung über die Verständigung. Zeitschrift für Internationale Beziehungen, 1, 133-147.

Raiffa, H. (1982). The art and science of negotiation. Cambridge, MA: Harvard University Press.

Risse, T. (2000). "Let's argue!" Communicative action in world politics. International Organization, 54, 1-39.

Risse, T., Ropp, S., \& Sikkink, K. (1999). The power of human rights. International norms and domestic change. Cambridge, England: Cambridge University Press.

Ritter, E.-H. (1979). Der kooperative Staat. Bemerkungen zum Verhältnis von Staat und Wirtschaft. Archiv für öffentliches Recht, 104, 389-413.

Roth, A. E. (1995). Bargaining experiments. In J. H. Kagel \& A. E. Roth (Eds.), The handbook of experimental economics (pp. 253-347). Princeton, NJ: Princeton University Press.

Saretzki, T. (1996). Wie unterscheiden sich Argumentieren und Verhandeln? Definitionsprobleme, funktionale Bezüge und strukturelle Differenzen von zwei verschiedenen Kommunikationsmodi. In V. von Prittwitz (Ed.), Verhandeln und Argumentieren. Dialog, Interessen und Macht in der Umweltpolitik (pp. 135-167). Opladen: Leske \& Budrich.

Scharpf, F. W. (1991). Die Handlungsfähigkeit des Staates am Ende des zwanzigsten Jahrhunderts. Politische Vierteljahresschrift, 32, 621-634.

Scharpf, F. W. (1993). Positive und negative Koordination in Verhandlungssystemen. Politische Vierteljahresschrift, 24, 57-83. 
Scharpf, F. W. (1997). Games real actors play: Actor-centered institutionalism and policy research. Boulder, CO: Westview Press.

Schimmelfennig, F. (1997). Rhetorisches Handeln in der internationalen Politik. Zeitschrift für Internationale Beziehungen, 4, 219-254.

Schneider, G. (1995). Rational Choice und kommunikatives Handeln. Eine Replik auf Harald Müller. Zeitschrift für Internationale Beziehungen, 2, 357-366.

Searle, J. R. (1969). Speech acts: An essay in the philosophy of language. Cambridge: Cambridge University Press.

Searle, John R. (1974). Was ist ein Sprechakt? In S. J. Schmidt (Ed.), Pragmatik I (pp. 84-102). München: Beck.

Searle, J. R. (1983). Sprechakte: Ein sprachphilosophischer Essay. Frankfurt.: Suhrkamp.

Susskind, Lawrenc, \& Cruikshank, Jeffrey (1987). Breaking the impasse: Consensual approaches to resolving disputes. New York: Basic Books.

Voigt, R. (1995). Der kooperative Staat: Krisenbewältigung durch Verhandlung? Baden-Baden: Nomos.

Appendix A

Illocutionary Acts in Bargaining and Arguing

\begin{tabular}{|c|c|}
\hline Bargaining & Arguing \\
\hline demand, require to, call for, desire & claim (facts and values) \\
\hline offer, to be willing to, to be prepared to & establish, mention (facts and values) \\
\hline suggest (e.g. a solution) & suspect, conjecture, believe, assume \\
\hline suggest a compromise & ask, want to know \\
\hline accommodate & inform, report \\
\hline $\begin{array}{l}\text { promise, confirm, commit oneself, give } \\
\text { one's word, vow to, guarantee }\end{array}$ & conclude (logically), infer \\
\hline $\begin{array}{l}\text { threaten, announce (withdrawal, } \\
\text { strategies outside the negotiation) }\end{array}$ & $\begin{array}{l}\text { justify, argue, give reasons, explain, clarify, } \\
\text { verify (empirically), prove (logically), } \\
\text { demonstrate (prove) }\end{array}$ \\
\hline $\begin{array}{l}\text { accept, endorse, approve of, consent } \\
\text { to, acquiesce, fall in with }\end{array}$ & approve, admit as correct \\
\hline decline, reject, refuse & $\begin{array}{l}\text { contradict, reject, dispute, call into doubt, } \\
\text { object }\end{array}$ \\
\hline concede, make concession, give way & $\begin{array}{l}\text { concede, grant, acknowledge, accept, } \\
\text { admit, recognize (factitive) }\end{array}$ \\
\hline $\begin{array}{l}\text { uphold (an offer, a call for, a } \\
\text { suggestion) }\end{array}$ & $\begin{array}{l}\text { insist, persist (with an opinion), stick to (a } \\
\text { belief) }\end{array}$ \\
\hline take back (offer, promise) & take back (arguments, claims) \\
\hline $\begin{array}{l}\text { ascertain unanimity (consensus); } \\
\text { ascertain a resolution, conclude } \\
\text { a contract }\end{array}$ & $\begin{array}{l}\text { ascertain agreement (consensus), establish } \\
\text { a result }\end{array}$ \\
\hline ascertain nonagreement & ascertain disagreement \\
\hline
\end{tabular}


Appendix B

Examples of Speech Act Records in the Database

\begin{tabular}{|c|c|c|c|}
\hline \multicolumn{2}{|l|}{ Bargaining } & \multicolumn{2}{|l|}{ Consensus } \\
\hline Source & $4,128,5083^{a}$ & Source & $3,084,3340^{a}$ \\
\hline Speaker & GRÜNEN (Green Party) & Speaker & mediator \\
\hline Group $^{b}$ & ge & Group $^{b}$ & me \\
\hline Illocutionary act & demand & Function & ask whether there is consensus \\
\hline Illocutionary indicator & würde ich darum bitten (I would like to ask for) & Substance & waste reduction, construction wastes \\
\hline Proposition & BMA as an alternative to MVA & & \\
\hline Level $^{c}$ & $\mathrm{~s}$ & Level $^{c}$ & $\mathrm{~s}$ \\
\hline Substantial goal & anti MVA & & \\
\hline Addressee & head of environmental department, county administration & Addressee & $\begin{array}{l}\text { BUND (Friends of the Earth), } \\
\text { county administration }\end{array}$ \\
\hline Reaction & mediator, accept & Reaction & $\begin{array}{l}\text { head of environmental department, } \\
\text { contradict }\end{array}$ \\
\hline
\end{tabular}


Thema (MVA) reden, dann würde ich darum bitten,

daß wir auch ernsthaft in Erwägung ziehen, daß es auch

andere Alternativen gibt, und daß die auch rechtlich

möglich sind, ja.

according to the prevalent law biological-mechanical

treatment would be approved ... . and if we talk about

this subject (incineration), then I would request that

we also seriously consider that there are also alternatives

to it and that those are acceptable from the legal point

of view, yes.

\begin{tabular}{lll}
\hline Arguing & Interest-oriented & Consensus-oriented \\
\hline Source & $2,35,1357^{a}$ & $4,146,5858^{a}$ \\
Speaker & BIgMV (citizens' initiative against waste incineration) & mediator \\
$\begin{array}{l}\text { Group } \\
\text { (Illocutionary act }\end{array}$ & ge & me \\
Illocutionary indicator & contradict & conclude \\
& ist natürlich auch so nicht richtig (this is obviously & wenn ... dann ... aber (if ... then .... however) \\
Communicative intention & justify the position that ... & searching for compromise \\
Proposition & there are too high health risks already in GvN; relates & $\begin{array}{l}\text { BMA needs an additional treatment facility for juridical } \\
\text { reasons (the mediator introduces with this speech act his } \\
\text { proposal to have a combination of treatment facilities) }\end{array}$
\end{tabular}


Appendix B

Examples of Speech Act Records in the Database (Continued)

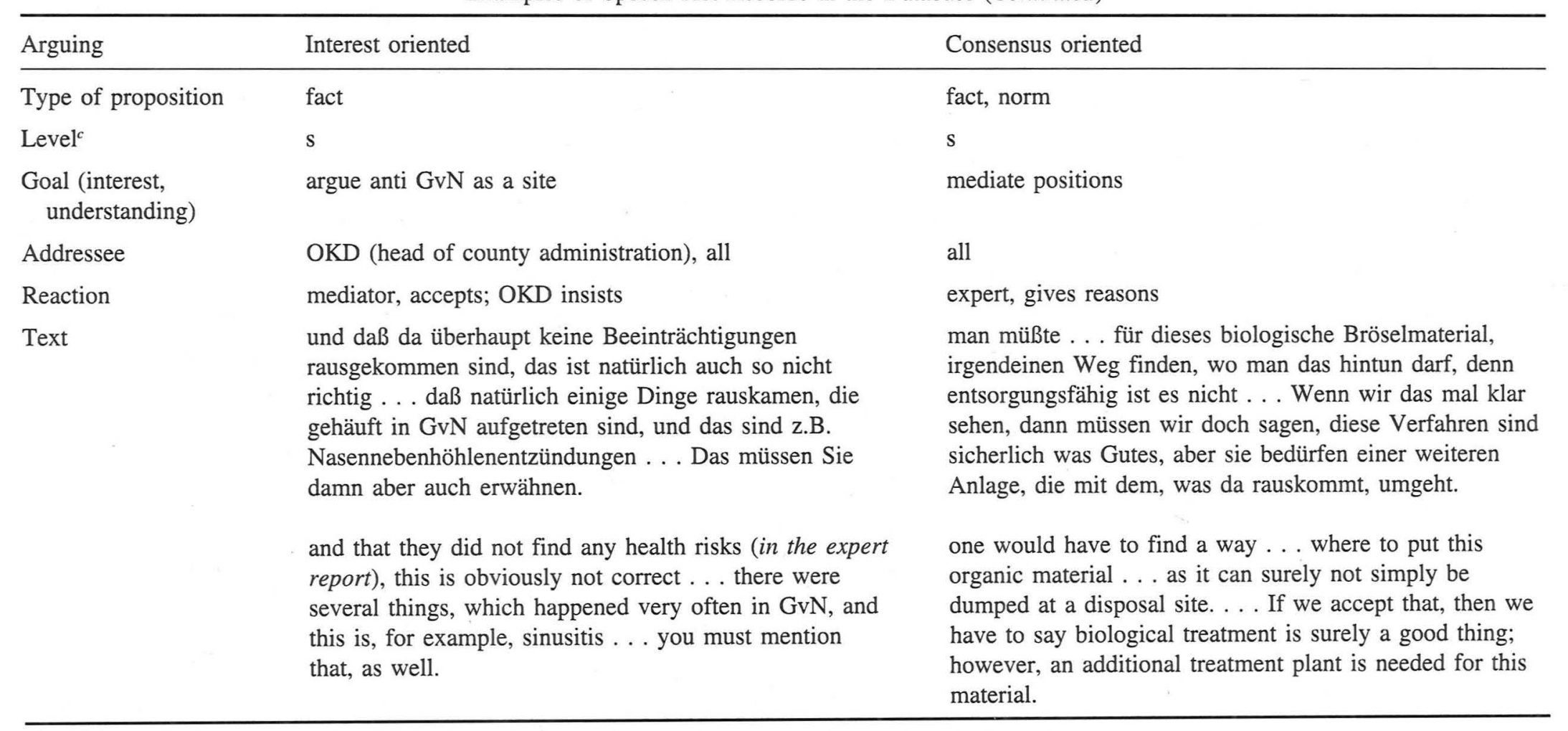

Note. $\mathrm{BMA}=$ biological-mechanic waste treatment; $\mathrm{MVA}=$ waste incineration plant; GvN = site Grevenbroich-Neurath.

${ }^{a}$ Number of meeting, page, line in transcript.

${ }^{b} \mathrm{ge}=$ opponents; $\mathrm{me}=$ mediator; be $=$ supporters; $\mathrm{gu}=$ experts .

$c_{\mathrm{S}}=$ substantial (conflict-related); $\mathrm{v}=$ procedure; $\mathrm{b}=$ relationship. 